\title{
TIBIAL FRACTURES WITH BONE LOSS TREATED BY PRIMARY REAMED INTRAMEDULLARY NAILING
}

\author{
C. M. ROBINSON, G. McLAUCHLAN, J. CHRISTIE, M. M. McQUEEN, C. M. COURT-BROWN
}

From the Edinburgh Royal Infirmary, Scotland

We reviewed the results of the treatment of 30 tibial fractures with minor to severe bone loss in 29 patients by early soft-tissue and bony debridement followed by primary locked intramedullary nailing. Subsequent definitive closure was obtained within the first $\mathbf{4 8}$ hours usually with a soft-tissue flap, and followed by bone-grafting procedures which were delayed for six to eight weeks after the primary surgery. The time to fracture union and the eventual functional outcome were related to the severity and extent of bone loss.

Twenty-nine fractures were soundly united at a mean of 53.4 weeks, with delayed amputation in only one patient. Poor functional outcome and the occurrence of complications were usually due to a departure from the standard protocol for primary management.

We conclude that the protocol produces satisfactory results in the management of these difficult fractures, and that intramedullary nailing offers considerable practical advantages over other methods of primary bone stabilisation.

J Bone Joint Surg [Br] 1995;77-B:906-13.

Received 1 March 1995; Accepted after revision 10 May 1995

C. M. Robinson, FRCS Ed, FRCS Ed(Orth), Clinical Lecturer and Honorary Senior Registrar

G. McLauchlan, FRCS, Orthopaedic Registrar

J. Christie, FRCS Ed(Orth), Consultant Orthopaedic Surgeon

M. M. McQueen, FRCS Ed(Orth), Consultant Orthopaedic Surgeon

C. M. Court-Brown, MD, FRCS Ed(Orth), Consultant Orthopaedic Surgeon

Orthopaedic Trauma Unit, Royal Infirmary of Edinburgh, 1 Lauriston Place, Edinburgh EH3 9YW, UK.

Correspondence should be sent to $\mathrm{Mr} \mathrm{C}$. M. Robinson.

()1995 British Editorial Society of Bone and Joint Surgery

0301-620X/95/61044 \$2.00
Overall, significant bone loss is seen in only a small percentage of tibial fractures but in open fractures it is found in 17\% to $40 \%$ (Karlström and Olerud 1983; Blick et al 1989; Maurer, Merkow and Gustilo 1989; Fischer, Gustilo and Varecka 1991). Nearly all such injuries result from high-energy trauma and usually have severe soft-tissue injury or loss, with damage to the remaining diaphyseal bone (Swiontkowski 1989). The treatment of these patients is therefore often prolonged and difficult. Various techniques of soft-tissue management, primary bone fixation and secondary reconstructive surgery have been described (Taylor, Miller and Ham 1975; Goldstrohm, Mears and Swartz 1984; Maurer and Dillin 1987; Christian, Bosse and Robb 1989). Standardisation of a treatment protocol is difficult because of the different bone and soft-tissue injury in each case.

Since 1988 in the Edinburgh Orthopaedic Trauma Unit, all fractures with significant bone loss have been managed under combined orthopaedic and plastic surgical care. Aggressive early wound toilet and locked intramedullary stabilisation of the tibia are followed by delayed soft-tissue cover, with bone grafting at 6 to 12 weeks after injury. We have reviewed the results of the treatment of 29 patients using this protocol.

\section{PATIENTS AND METHODS}

Between August 1988 and August 1993, 649 tibial diaphyseal fractures were treated in the Edinburgh Orthopaedic Trauma Unit by locked intramedullary nailing. During this period primary amputations were performed for 12 fractures with bone loss in which the limb could not be saved because of severe crush injury, severe nerve injury with loss of sensation to the foot, or irrepairable vascular damage. Excluding fractures with small devitalised fragments of less than $0.5 \mathrm{~cm}$ in length involving less than $25 \%$ of the circumference of the tibia, there were 30 diaphyseal fractures (4.6\%) with significant bone loss in 29 patients with viable limbs which were suitable for intramedullary nailing.

We considered this method to be inappropriate for fractures with bone loss in the proximal or distal metaphyses or those with severe intra-articular extension. These fractures were treated either by an external fixator with or without open reduction and internal fixation.

There were 22 men and 7 women whose average age was 
40.8 years (18 to 78). Twenty-six of the 30 fractures had been caused by road-traffic accidents in 25 patients $(85 \%)$; 18 were pedestrians and 7 were car or motorcycle drivers. Of the other four fractures, three were due to falls from a height and one to a sports injury. There were additional orthopaedic injuries in 17 patients $(58.6 \%)$ and $8(27.6 \%)$ had injuries to other body systems.

All 30 fractures had Gustilo grade-IIIb open wounds (Gustilo and Anderson 1976), and on the AO system of classification (Müller et al 1990), $19(63.3 \%)$ were type 42 $\mathrm{B}$ and $11(36.7 \%)$ were type $42 \mathrm{C}$. The fracture was in the proximal third of the diaphysis in three cases, the middle third in nine and in the distal third in seven. There was complete segmental loss in the proximal and middle thirds in five fractures and in the middle and distal thirds in six.

The severity of the bone loss was assessed radiologically and clinically at the time of operation. The bone defects were due either to extruded fragments or to segments completely devoid of blood supply at the time of debridement. The loss was either wedge-shaped or circumferential; the extent of loss of bone circumference and the maximal length of bone loss were measured. We graded the severity of the bone loss by a modification of the method devised by Winquist and Hansen (1980) for the assessment of femoral fractures (Table I).

The fractures were managed by aggressive soft-tissue and bone toilet with irrigation. Careful assessment was made of the vascularity of all remaining soft tissue and bone left in place. Intramedullary nailing of the tibia was carried out using the technique which we have previously described for open fractures (Court-Brown et al 1991). Reaming was not undertaken over areas of bone loss to prevent damage to the exposed soft tissues. Standard antibiotic prophylaxis was given for 48 hours. We used the ipsilateral fibular length and the length of the contralateral intact tibia as guides to the original length of the injured tibia, with static locking in all to restore length and prevent later shortening.

At the primary operation all wounds were left open; reinspection was carried out by a plastic surgeon within 48 hours. If the wounds were satisfactory, soft-tissue cover was completed. The method of cover used was related to the extent of damage to the surrounding soft tissues.

Table I. Classification of the severity of bone loss (modified from Winquist and Hansen 1980)

\begin{tabular}{lll}
\hline Grade & Maximal bone loss & $\begin{array}{l}\text { Maximum length } \\
\text { of bone loss }(\mathrm{cm})\end{array}$ \\
\hline Trivial & Wedge $<25 \%$ & \\
Minor & Wedge $25 \%$ to $50 \%$ & \\
& Wedge $>50 \%$ but $<100 \%$ & $<2.5$ \\
Moderate & Wedge $>50 \%$ but $<100 \%$ & 2.5 to 10 \\
& Circumferential & $<2.5$ \\
Severe & Wedge $>50 \%$ but $<100 \%$ & $>10$ \\
& Circumferential & $>2.5$ \\
\hline
\end{tabular}

If other injuries permitted, protected weight-bearing was allowed as soon as the state of the soft tissues was satisfactory. Early active and passive knee, ankle and subtalar joint movement was encouraged as soon as possible after surgery. No casts were used, except for patients who were unconscious or required prolonged respiratory support on ventilators, who had backshells applied to prevent the development of contractures at the ankle.

A decision with regard to the method and timing of secondary bony reconstruction was made after six weeks. The methods included exchange nailing and open bone grafting as determined by the severity of bone loss. Exchange nailing was by the technique described by us (Court-Brown et al 1991). Open bone grafting with autogenous cancellous bone from the iliac crest used either an anterior or a posterolateral approach (Harmon 1945), depending on the location of the bone loss and the state of the soft tissues.

For the purpose of this review, patients were assessed at least six months after union with a mean follow-up of 38 months (6 to 78). The criteria for bone union, malunion and bony infection were those defined previously in other reviews of tibial nailing (Court-Brown, Christie and McQueen 1990; Court-Brown et al 1991). All operative and postoperative complications were documented, and a short questionnaire was used to assess residual pain and disability. Patients with absence of significant leg pain and unrestricted resumption of the preinjury level of activity were recorded as having normal function. Those in whom daily activities could be carried out at a reduced tempo or with modification to lifestyle with residual discomfort in the leg were recorded as having impaired function; those with severe pain, severe restriction of daily activities, or who required walking aids were termed disabled. We also assessed the ranges of knee, ankle and subtalar movement, recording restriction of movement as a percentage of full joint movement.

\section{RESULTS}

Of the 30 fractures treated 29 united at a mean of 53.4 weeks (20 to 98). The major complications were infection in six fractures $(20 \%)$, which led to amputation in one (3.3\%), and malunion in four (13.3\%). The details of the soft-tissue cover, secondary bony procedures, complication rates and final functional outcome are summarised in Tables II and III. Three groups of patients were considered separately, based on the severity of the initial bone loss. Minor bone loss. Nine patients had AO type $42 \mathrm{~B}$ fractures with small devascularised wedge fragments (Table I); their mean age was 48.2 years ( 34 to 46 ). Five had bone loss of less than $50 \%$ of the bone circumference and four had loss of more than $50 \%$. The mean maximal loss of length was $2.1 \mathrm{~cm}$. All these fractures united at a mean time of 32.4 weeks (20 to 48 ). When exchange nailing was considered necessary this was performed at between 16 and 22 weeks 


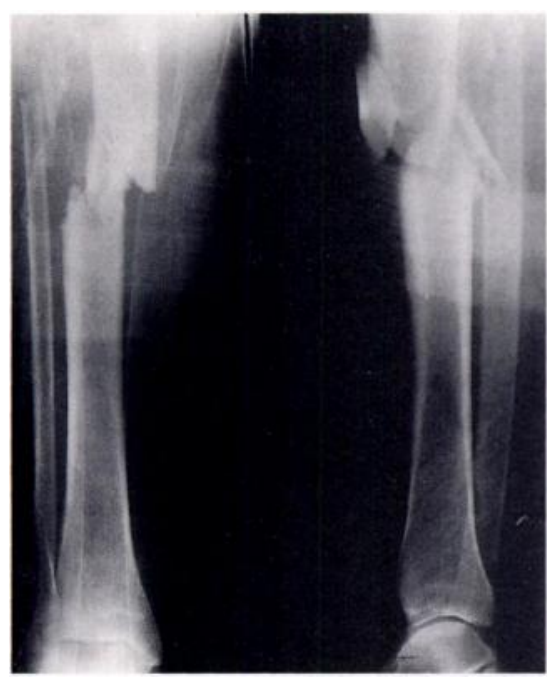

Fig. la

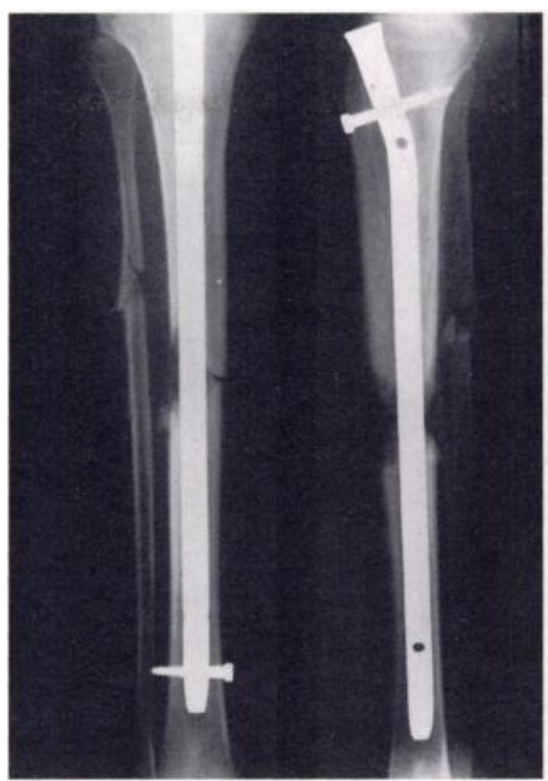

Fig. Ib

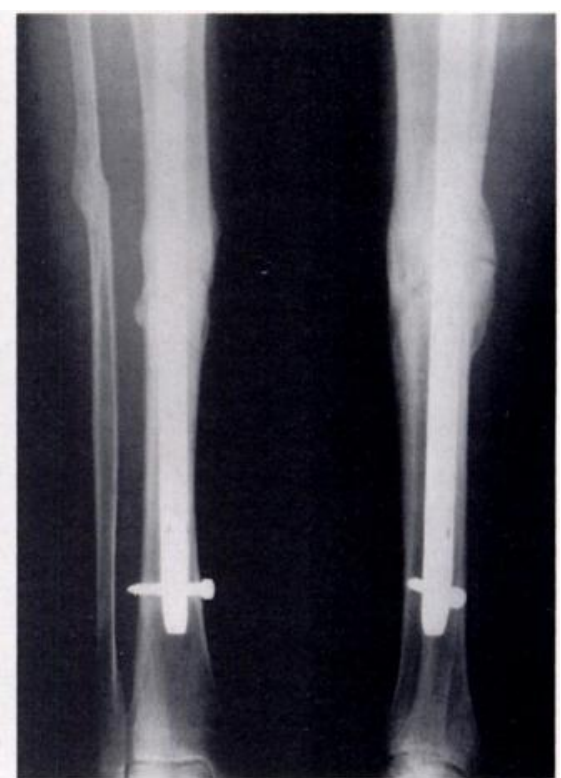

Fig. 1c

Minor bone loss. At exploration of the Gustilo type-IIlb wound there were two completely devitalised wedges of bone (a). After stabilisation with a locked Grosse-Kempf nail cortical apposition was preserved over $20 \%$ of the circumference and the maximal length of wedge loss was under $2.5 \mathrm{~cm}$ (b). Exchange nailing was performed at 20 weeks. and the fracture had healed by 35 weeks (c).

Table II. Details of the management in the three groups of open fracture

\begin{tabular}{lll}
\hline Bone loss & Soft-tissue cover & Secondary bony procedure \\
\hline $\begin{array}{l}\text { Minor } \\
(\mathrm{n}=9)\end{array}$ & $\begin{array}{l}\text { Fasciocutaneous flap (6) } \\
\text { Split-skin graft (3) }\end{array}$ & Exchange nailing (4) \\
$\begin{array}{l}\text { Moderate } \\
(\mathrm{n}=11)\end{array}$ & $\begin{array}{l}\text { Fasciocutaneous flap (5) } \\
\text { Split-skin graft (4) }\end{array}$ & $\begin{array}{l}\text { Exchange nailing (2) } \\
\text { Bone graft (10)* }\end{array}$ \\
$\begin{array}{l}\text { Secondary suture (2) } \\
\text { Severe } \dagger\end{array}$ & $\begin{array}{l}\text { Fasciocutaneous flap (4) } \\
(\mathrm{n}=10)\end{array}$ & Bone graft (10) \\
& Free flap (3) & \\
\hline
\end{tabular}

* in two fractures this followed failure of exchange nailing tten fractures in nine patients

Table III. Infection, malunion and functional outcome in the three groups of open fracture

\begin{tabular}{|c|c|c|c|}
\hline Bone loss & Infection & Malunion & Functional outcome \\
\hline $\begin{array}{l}\text { Minor } \\
(n=9)\end{array}$ & 1 & 0 & $\begin{array}{l}\text { Normal } 7 \\
\text { Impaired } 2 \\
\text { Disabled } 0\end{array}$ \\
\hline $\begin{array}{l}\text { Moderate } \\
(n=11)\end{array}$ & 2 & 1 & $\begin{array}{l}\text { Normal } 7 \\
\text { Impaired } 0 \\
\text { Disabled } 4\end{array}$ \\
\hline $\begin{array}{l}\text { Severe* } \\
(\mathrm{n}=10)\end{array}$ & 3 & 3 & $\begin{array}{l}\text { Normal } 2 \\
\text { Impaired } 4 \\
\text { Disabled } 2 \div\end{array}$ \\
\hline
\end{tabular}

* ten fractures in nine patients

$\dagger$ one had a below-knee amputation

(Fig. 1). The single infection (Table III) was at the site of a skin graft after exchange nailing. After further debridement a flap was applied and there was union without recurrence of infection at 48 weeks.

Seven patients with minor bone loss had regained full function at review, two had some impairment of function but had returned to work with modification of activities (Table III). One patient had 50\% loss of subtalar movement but no others had any joint stiffness or ankle contracture.

Moderate bone loss. Eleven patients had either devascularised wedge fragments of up to $10 \mathrm{~cm}$ in length or circumferential loss of up to $2.5 \mathrm{~cm}$ (Table I). Their mean age was 41.7 years ( 18 to 78 ). There were nine AO type 42 $\mathrm{B}$ fractures, with mean maximal loss of $5.1 \mathrm{~cm} \mathrm{(3} \mathrm{to} \mathrm{8)} \mathrm{and}$ two AO type $42 \mathrm{C}$ fractures with losses of 2 and $2.5 \mathrm{~cm}$ respectively.

These fractures united at a mean time of 42.6 weeks (35 to 56). Ten required secondary bone grafting to promote union (Table II); seven had this between 7 and 12 weeks after injury (Fig. 2) and six of these united without further surgery. One required further grafting at 48 weeks. The other three fractures were not bone grafted at an early stage as they were considered to have less severe wedge losses but all three subsequently failed to unite, despite exchange nailing in two. All three fractures ultimately required open bone grafts between 20 and 24 weeks.

One patient, with a loss of $60 \%$ of the tibial circumference over a maximal length of $4 \mathrm{~cm}$, had a cerebrovascular accident six weeks after operation. He was unfit for further surgery, but the residual bony bridge eventually consolidated.

In the two cases of infection in this group, split skin had been used to cover the soft-tissue defect. One patient with early infection after this showed devitalised infected bone 

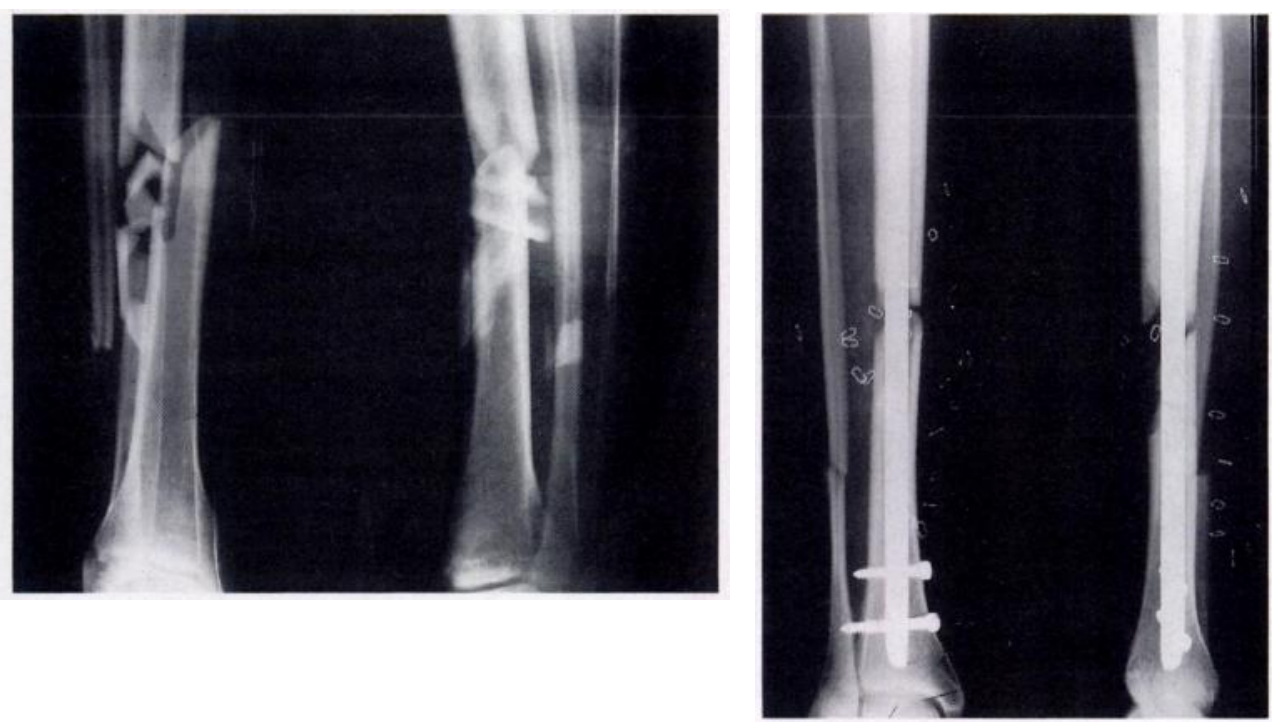

Fig. 2a

Fig. $2 b$

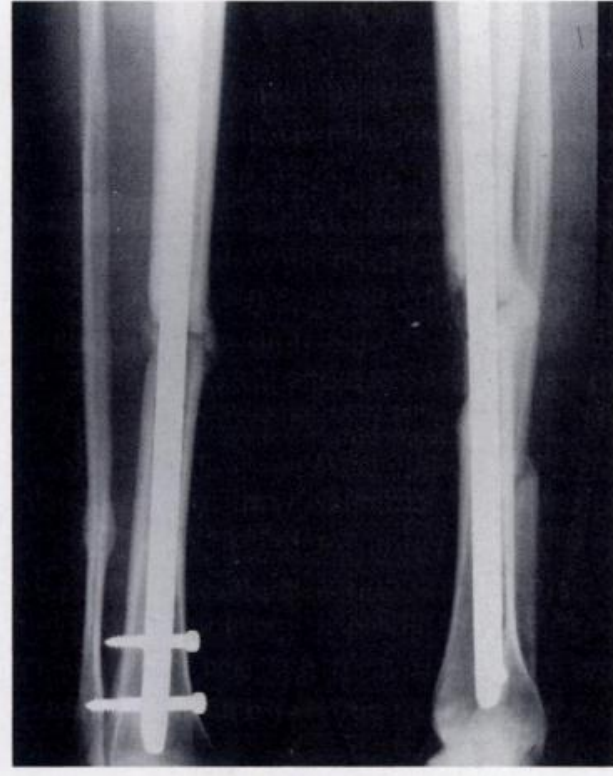

Fig. 2c

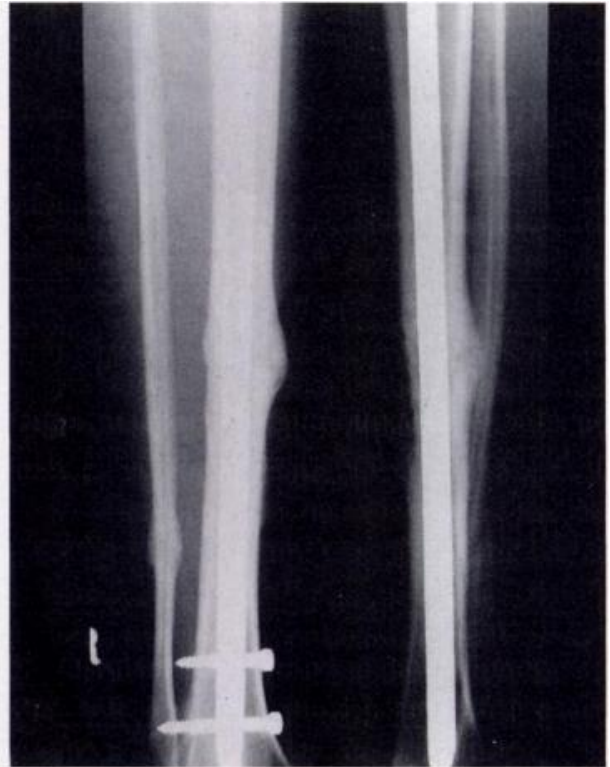

Fig. $2 d$

Moderate bone loss. At exploration of the Gustilo type- IIIb wound, two devitalised bone wedges were removed (a). After stabilisation with a Grosse-Kempf nail cortical continuity was present over $10 \%$ of the residual bone circumference, and the maximal length of wedge loss was $6 \mathrm{~cm}$ (b). Open grafting with morsellised. cancellous. iliac-crest bone was performed at eight weeks (c), and the fracture had healed by 38 weeks (d).

at re-exploration. This was resected and a fasciocutaneous flap applied. The other patient became infected after exchange nailing. Re-exploration revealed a local purulent collection but the bone appeared healthy and only softtissue debridement was needed. Both fractures subsequently united without recurrence of infection and with the nail still in position.

Seven patients in this group regained full function with no disability but four were disabled (Table III). Two of these had dense ipsilateral hemiplegia, one as a result of a head injury and the other due to a cerebrovascular accident.
Both patients had restriction of ankle movement by more than $50 \%$ with equinus deformities of $10^{\circ}$ and $15^{\circ}$. The other two disabled patients were aged 72 and 78 years and had required walking aids before their injury. Both had residual discomfort at the ankle with reduction of ankle and subtalar movement by $50 \%$. Two other patients also had asymptomatic restriction of knee, ankle or subtalar movement by less than $25 \%$.

Severe bone loss. There were ten fractures with severe bone loss in nine patients with a mean age of 36 years ( 18 to 72). Nine of these fractures ( $\mathrm{AO}$ type $42 \mathrm{C}$ ) had a mean 


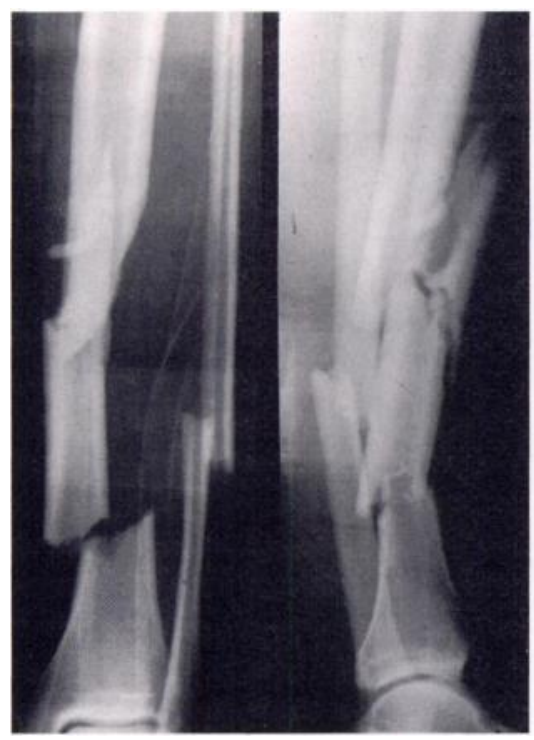

Fig. 3a

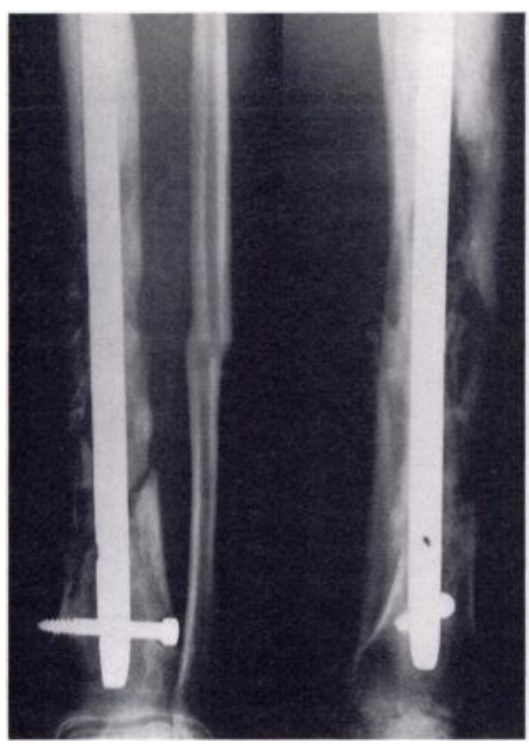

Fig. 3b

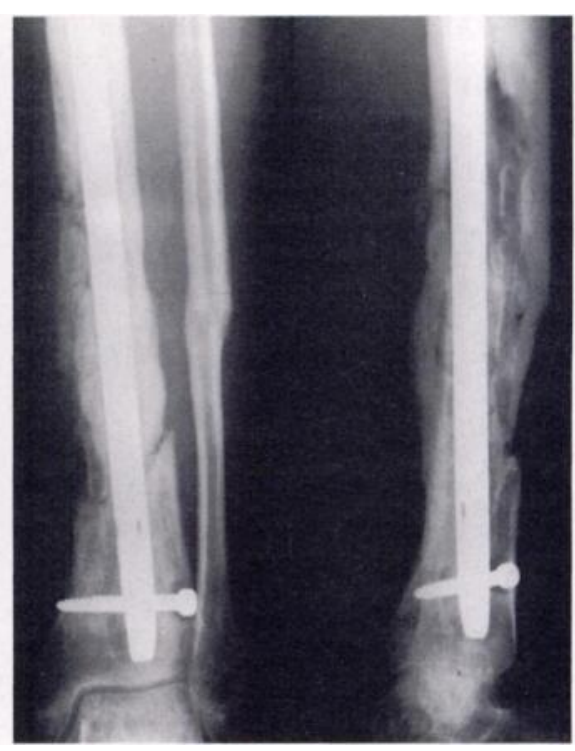

Fig. 3c

Severe bone loss. At exploration of the Gustilo type-IIIb wound the intermediate bone segment was contaminated and devoid of soft-tissue attachment (a). It was removed, and a locked Grosse-Kempf nail left a circumferential defect of $9 \mathrm{~cm}$. After definitive soft-tissue flap cover, open bone grafting with morsellised cancellous iliac-crest bone was performed at nine weeks (b). and repeated at 27 and 45 weeks. The fracture had united by 75 weeks (c).

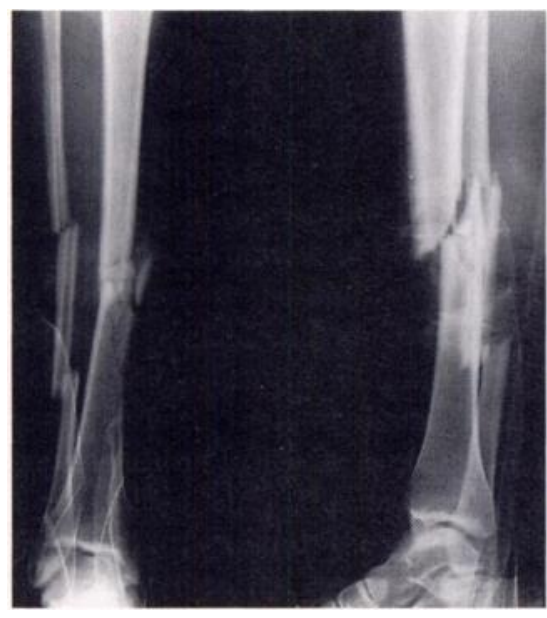

Fig. $4 \mathrm{a}$

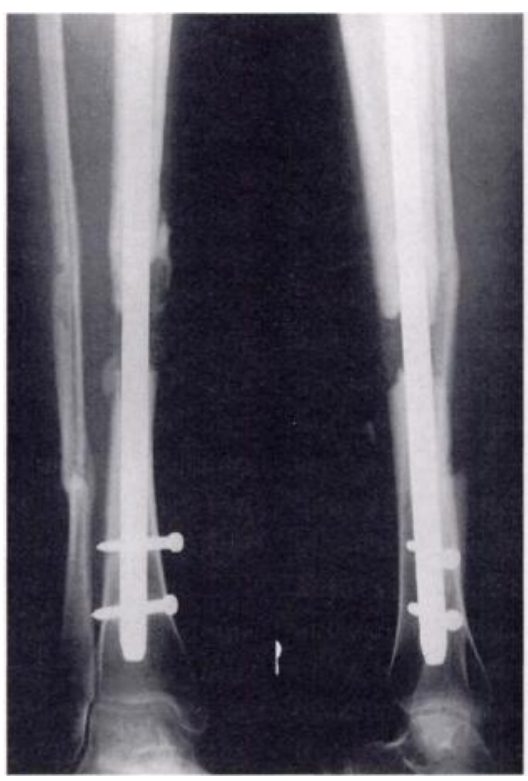

Fig. 4b

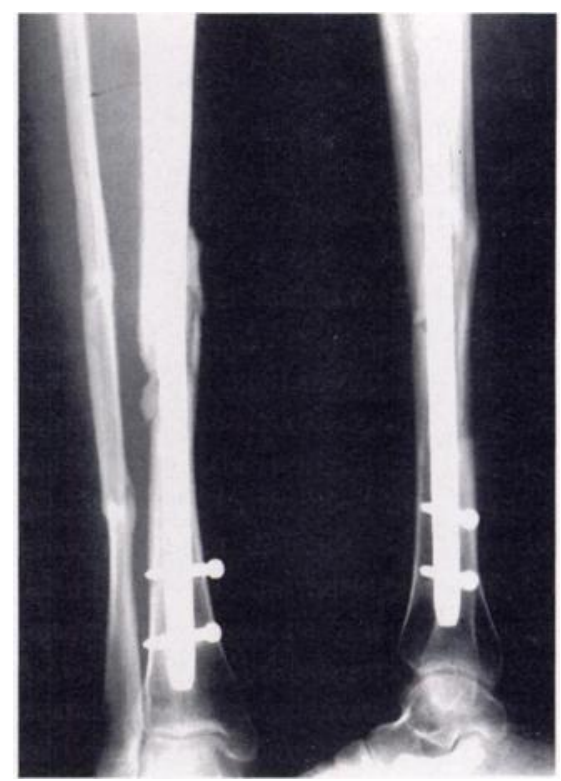

Fig. $4 \mathrm{c}$

Severe bone loss. At exploration of the Gustilo type-IIIb wound the comminuted wedge fragments were removed (a). After locked nailing the maximal length of the circumferential defect was $5 \mathrm{~cm}$. Subsequent open grafting, with cancellous iliac-crest chips, was performed at eight weeks (b) and at 26 weeks. The fracture had united by 68 weeks (c).

loss of $7.3 \mathrm{~cm} \mathrm{(3} \mathrm{to} 10)$, and one had a large solitary devascularised wedge fragment of $11 \mathrm{~cm}$.

Nine fractures united at a mean of 70.5 weeks (66 to 98), but one patient eventually required a below-knee amputation. Bone grafting was performed at between 8 and 12 weeks in all cases, but was successful in only two fractures. Five fractures required a second bone graft and three required a third (Figs 3 and 4). A synostosis between the tibia and fibula developed in three cases.

The three infections in this group were all in patients initially treated by split-skin grafting to cover the softtissue defect. The infection was controlled in two by early exploration and debridement, followed by the application of a fasciocutaneous flap. In the patient who eventually 
required amputation, infection persisted despite these measures and amputation was eventually carried out 44 weeks after the injury.

Of the eight patients with nine united fractures, only two recovered full function. Four patients with impaired function were able to return to work or daily activities with some modification of their daily tasks. One disabled patient had a severe head injury and one had bilateral tibial fractures with bone loss. Full knee, ankle and subtalar movement was regained in only four limbs, but in four movements were restricted by less than $25 \%$. The patient disabled by a head injury had $50 \%$ restriction of ankle and subtalar movement and a fixed $15^{\circ}$ equinus deformity of the ankle.

\section{DISCUSSION}

Tibial fractures with bone loss usually result from highenergy trauma which produces severe injuries to both the soft tissues and the surviving tibial fragments. Considerable delay in union must be expected with a prolonged period of treatment. In such cases the indications for limb salvage have been questioned (Hansen 1987; Heatley 1988), but improvement in techniques of bone fixation and soft-tissue cover appears to have given better results over the last 15 years (Chacha 1973; Caudle and Stern 1987).

The classification and prognosis of these severe injuries are difficult because of variation in the extent of skin degloving, muscle contusion, periosteal stripping and bone loss (Rosenthal, MacPhail and Ortiz 1977; Lange et al 1985) which are not easy to quantify. The most widely accepted classification of soft-tissue injury in open fractures is that of Gustilo and Anderson (1976), but this does not include assessment of bone loss. Previous work in our unit has shown that Gustilo type-IIIb injuries with bone loss have more delay in union and require more secondary reconstructive procedures than type-IIIb fractures without bone loss (Court-Brown et al 1991). We have now refined our classification of initial bone loss and based it on both operative and radiological findings; this has provided a more sensitive guide to the outcome.

As expected, the time to union for fractures with moderate and severe bone defects was longer than that which we have previously reported for Gustilo type-II and type-III open fractures without bone loss, also treated by nailing (Court-Brown et al 1991). Union was achieved, however, in all but one fracture, but the time taken was directly related to the amount of bone loss. The proportion of patients who regained full function was also related to bone loss, although five of the 13 patients with impairment had either other injuries or poor function before operation. If the distal limb appears to be viable at presentation attempts at limb salvage appear to be worthwhile even in cases with severe bone loss.

Management protocols have to be flexible because of the wide variation in the extent and severity of injury. They should provide effective guidelines for treatment during the immediate phase (6 to 8 hours after injury), the early phase (first week) and the delayed phase (after the first week).

It is generally agreed that the early treatment of soft tissues and bone includes thorough excision of all contaminated and devitalised tissue and 'therapeutic' levels of antibiotics for $\mathbf{4 8}$ hours to prevent infection, which is the major cause of failure (Damholt 1982; Swiontkowski 1989). Although there is evidence in favour of the use of intramedullary nailing in the early treatment of uncomplicated open tibial fractures (CourtBrown et al 1991; Tornetta et al 1994), its use in fractures with bone loss has not previously been described. Most authors favour the use of an external fixator for the stabilisation of these injuries (Karlström and Olerud 1983; Velazco and Fleming 1983; Edwards et al 1988; Blick et al 1989; Christian et al 1989).

We consider that nailing offers considerable practical advantages over external fixation. The gains include earlier weight-bearing, easier access for secondary soft-tissue and bony procedures, a reduced malunion rate and better patient tolerance. Furthermore, it avoids the risks of pin-track infection, which is seen in up to $80 \%$ of cases during prolonged external fixation (Velazco and Fleming 1983) and of late refracture.

Direct comparison with previous reports of the use of external fixation for such cases is impossible, because fractures with bone loss are usually included in the whole spectrum of open fractures. The rates of infection and of failure of treatment reported in such series, however, appear to be similar to those which we report using intramedullary nailing (Table IV).

The status of soft tissues has been considered to be the most important factor determining the ultimate prognosis (Urist, Mazet and McLean 1954; Carpenter 1966). In our series there were no early infections after early flap cover; all six infections appeared to be related to deficiencies in the early phase of soft-tissue management. Five of the six infections were controlled by further debridement and the application of fasciocutaneous flaps. The importance of the soft-tissue blood supply for both fracture healing and the survival of bone grafts has been shown experimentally (Stringa 1957; Holden 1972) and the advantages of flap cover over local skin cover have been demonstrated (Richards et al 1991). We now consider that flap cover should be the routine treatment for soft-tissue defects in open fractures with bone loss.

The secondary bony procedures required during the delayed phase of treatment were determined by the extent of initial bone loss. Patients with minor bone loss were initially managed expectantly, although further treatment was required for delayed union in nearly half of them. It is useful to make a careful clinical and radiological reassessment of fracture healing at between 16 and 20 weeks after injury. Lack of advanced signs of union at this stage was treated successfully by exchange nailing.

Fractures with circumferential bone loss of greater than 
Table IV. Comparison of results with reports of the use of external fixation for severe open tibial fractures

\begin{tabular}{|c|c|c|c|c|c|c|}
\hline Authors & $\begin{array}{l}\text { Number of fractures } \\
+ \text { Gustilo grade }\end{array}$ & Treatment & $\begin{array}{l}\text { Mean union } \\
\text { time (wks) }\end{array}$ & $\begin{array}{l}\text { Malunion } \\
\text { rate } \\
\text { (percent) }\end{array}$ & $\begin{array}{l}\text { Failed } \\
\text { treatment } \\
\text { (percent) }\end{array}$ & $\begin{array}{l}\text { Infection } \\
\text { rate } \\
\text { (percent) }\end{array}$ \\
\hline Velazco and Fleming (1983) & $\begin{array}{l}40 \text { mixed type II/III } \\
\text { (bone loss not recorded) }\end{array}$ & $\begin{array}{l}\text { External } \\
\text { fixation }\end{array}$ & $85 \%$ at 78 & $\mathrm{NR}^{*}$ & 12.5 & 12.5 \\
\hline Chan et al (1984) & $\begin{array}{l}17 \text { mixed type III } \\
(80 \% \text { with bone loss) }\end{array}$ & $\begin{array}{l}\text { External } \\
\text { fixation }\end{array}$ & $50 \%$ at 64 & 41 & 6 & 35 \\
\hline Caudle and Stern (1987) & $\begin{array}{l}62 \text { mixed type III } \\
\text { (bone loss not recorded) }\end{array}$ & $\begin{array}{l}\text { External } \\
\text { fixation }\end{array}$ & NR & NR & 21 & 26 \\
\hline Edwards et al (1988) & $\begin{array}{l}202 \text { mixed type III } \\
\text { ( } 83 \% \text { with bone loss) }\end{array}$ & $\begin{array}{l}\text { External } \\
\text { fixation }\end{array}$ & 38 & 12 & 7 & 15 \\
\hline Christian et al (1989) & $\begin{array}{l}9 \text { IIIb } \\
\text { (all with bone loss) }\end{array}$ & $\begin{array}{l}\text { External } \\
\text { fixation }\end{array}$ & 38 & NR & NR & 22 \\
\hline Blick et al (1989) & $\begin{array}{l}53 \text { mixed open } \\
\text { and closed }\end{array}$ & $\begin{array}{l}\text { External } \\
\text { fixation }\end{array}$ & 45 & NR & 4 & 28 \\
\hline Robinson et al (1995) & $\begin{array}{l}30 \text { IIIb } \\
\text { (all with bone loss) }\end{array}$ & $\begin{array}{l}\text { Intramedullary } \\
\text { nailing }\end{array}$ & 53 & 13 & 3 & 20 \\
\hline
\end{tabular}

* not recorded

$2.5 \mathrm{~cm}$ require early bone grafting (Blick et al 1989; Sledge et al 1989; Court-Brown et al 1991); this applied to all the fractures in our series with moderate or severe losses of bone. The early elective use of bone grafting at between 8 and 12 weeks for moderate bone loss appears to be justified; fractures with severe bone loss may require repeated grafting. This method of treatment is not as technically demanding as some of the more specialised alternatives such as vascularised or free segmental bone transfers (Weiland 1981; Ito, Kohno and Kojima 1984; Salibian, Anzel and Salyer 1987), bone transport (Ilizarov 1989a,b; Dagher and Roukoz 1991) or segmental bone transport over an unreamed nail (Raschke et al 1992) and no special instrumentation or implants are required.

Conclusions. We consider that the successful treatment of tibial fractures with bone loss depends on maintaining a satisfactory infection-free environment for bone healing. This implies immediate wound toilet with excision of all tissue of doubtful viability, fracture stabilisation, early reconstruction of the soft-tissue envelope with a wellvascularised flap, and secondary bony reconstruction according to the severity of bone loss.

The theoretical arguments against the use of intramedullary nailing as a method of primary bone stabilisation in open tibial fractures have not been borne out in practice and the use of this technique offers considerable advantages over external fixation.

No benefits in any form have been received or will be received from a commercial party related directly or indirectly to the subject of this article.

\section{REFERENCES}

Blick SS, Brumback RJ, Lakatos R, Poka A, Burgess AR. Early prophylactic bone grafting of high-energy tibial fractures. Clin Orthop 1989;240:21-41.

Carpenter EB. Management of fractures of the shaft of the tibia and fibula. J Bone Joint Surg [Am] 1966;48-A:1640- 6.

Caudle RJ, Stern PJ. Severe open fractures of the tibia. J Bone Joint Surg [Am] 1987;69-A:801-7.

Chacha PB. Salvage of severe open fractures of the tibia that might have required amputation. Injury 1973;6:154-72.

Chan KM, Leung YK, Cheng JCY, et al. The management of type III open tibial fractures. Injury 1984;16:157-65.

Christian EP, Bosse MJ, Robb G. Reconstruction of large diaphyseal defects, without free fibular transfer, in grade-IIIB tibial fractures. $J$ Bone Joint Surg [Am] 1989;71-A:994-1004.

Court-Brown CM, Christie J, McQueen MM. Closed intramedullary tibial nailing: its use in closed and type I open fractures. $J$ Bone Joint Surg $[\mathrm{Br}]$ 1990;72-B:605-11.

Court-Brown CM, McQueen MM, Quaba AA, Christie J. Locked intramedullary nailing of open tibial fractures. J Bone Joint Surg [Br] 1991;73-B:959-64.

Dagher F, Roukoz S. Compound tibial fractures with bone loss treated by the Ilizarov technique. J Bone Joint Surg [Br] 1991;73-B:316-21.
Damholt VV. Treatment of chronic osteomyelitis: a prospective study of 55 cases treated with radical surgery and primary wound closure. Acta Orthop Scand 1982;53:715-20.

Edwards CC, Simmons SC, Browner BD, Weigel MC. Severe open tibial fractures. Clin Orthop 1988;230:98-115.

Fischer MD, Gustilo RB, Varecka TF. The timing of flap coverage, bone-grafting, and intramedullary nailing in patients who have a fracture of the tibial shaft with extensive soft-tissue injury. $J$ Bone Joint Surg [Am] 1991;73-A:1316-22.

Goldstrohm GL, Mears DC, Swartz WM. The results of 39 fractures complicated by major segmental bone loss and/or leg length discrepancy. J Trauma 1984;24:50-8.

Gustilo RB, Anderson JT. Prevention of infection in the treatment of one thousand and twenty-five open fractures of long bones: retrospective and prospective analysis. J Bone Joint Surg [Am] 1976;58-A:453-8.

Hansen ST Jr. Editorial. The type-lIIC tibial fracture: salvage or amputation. J Bone Joint Surg [Am] 1987;69-A:799-800.

Harmon PH. A simplified surgical approach to the posterior tibia for bone-grafting and fibular transference. J Bone Joint Surg 1945; 27:496-8.

Heatley FW. Severe open fractures of the tibia: the courage to amputate [editorial]. Br Med J 1988;296:229. 
Holden CEA. The role of blood supply to soft tissue in the healing of diaphyseal fractures: an experimental study. J Bone Joint Surg [Am] 1972;54-A:993-1000.

Ilizarov GA. The tension-stress effect on the genesis and growth of tissues: part I. The influence of stability of fixation and soft-tissue preservation. Clin Orthop 1989a;238:249-81.

Ilizarov GA. The tension-stress effect on the genesis and growth of tissues: part II. The influence of the rate and frequency of distraction. Clin Orthop 1989b;239:263-85.

Ito T, Kohno T, Kojima T. Free vascularised fibular graft. J Trauma 1984;24:756-60.

Kariström G, Olerud S. External fixation of severe open tibial fractures with the Hoffmann frame. Clin Orthop 1983;180:68-77.

Lange RH, Bach AW, Hansen ST Jr, Johansen KH. Open tibial fractures with associated vascular injuries: prognosis for limb salvage. J Trauma 1985;25:203-8.

Maurer RC, Dillin L. Multistaged surgical management of posttraumatic segmental tibial bone loss. Clin Orthop 1987;216:162-70.

Maurer DJ, Merkow RL, Gustilo RB. Infection after intramedullary nailing of severe open tibial fractures initially treated with external fixation. J Bone Joint Surg [Am] 1989;71-A:835-8.

Müller ME, Nazarian S, Koch P, Schatzker J. The comprehensive classification of fractures of long bones. Berlin, etc: Springer-Verlag, 1990.

Raschke MJ, Mann JW, Oedekoven G, Claudi BF. Segmental transport after unreamed intramedullary nailing: preliminary report of a 'monorail' system. Clin Orthop 1992;282:233-40.

Richards RR, McKee MD, Paitich CB, Anderson GI, Bertoia JT. A comparison of the effects of skin coverage and muscle flap coverage on the early strength of union at the site of osteotomy after devascularisation of a segment of canine tibia. J Bone Joint Surg [Am] 1991;73-A:1323-30.
Rosenthal RE, MacPhail JA, Ortiz JE. Non-union in open tibial fractures: analysis of reasons for failure of treatment. J Bone Joint Surg [Am] 1977;59-A:244-8.

Salibian AH, Anzel SH, Salyer WA. Transfer of vascularised grafts of iliac bone to the extremities. J Bone Joint Surg [Am] 1987;69-A: 1319-27.

Sledge SL, Johnson KD, Henley MB, Watson JT. Intramedullary nailing with reaming to treat nonunion of the tibia. J Bone Joint Surg [Am] 1989;71-A:1004-19.

Stringa G. Studies of the vascularisation of bone grafts. J Bone Joint Surg [Br] 1957;39-B:395-420.

Swiontkowski MF. Criteria for bone debridement in massive lower limb trauma. Clin Orthop 1989;243:41-7.

Taylor GI, Miller GD, Ham FJ. The free vascularised bone graft: a clinical extension of microvascular techniques. Plast Reconstr Surg 1975;55:533-44.

Tornetta P III, Bergman M, Watnik N, Berkowitz G, Steuer J. Treatment of grade IIIB open tibial fractures: a prospective randomised comparison of external rotation and non-reamed locked nailing. J Bone Joint Surg [Br] 1994;76-B:13-9.

Urist MR, Mazet R Jr, McLean FC. The pathogenesis and treatment of delayed and non-union: a survey of eighty-five uncemented fractures of the shaft of the tibia and one hundred control cases with similar injuries. J Bone Joint Surg [Am] 1954;36-A:931-68.

Velazco A, Fleming LL. Open fractures of the tibia treated by the Hoffmann external fixator. Clin Orthop 1983;180:125-32.

Weiland AJ. Vascularized free bone transplants. J Bone Joint Surg [Am] 1981;63-A:166-9.

Winquist RA, Hansen ST Jr. Comminuted fractures of the femoral shaft treated by intramedullary nailing. Orthop Clin North Am 1980;11: 633-48. 